Oslo, 5. januar 2015

\title{
Prioriteringsutvalgets innstilling
}

\section{(NOU 2014:12)}

Forklaring av utvalgets forslag med kritiske kommentarer til prosess, analyser og anbefalinger.

Målgruppe: Helse- og omsorgsdepartementet, diverse høringsinstanser, interesserte forskere og almenhet, og utvalget selv.

\section{Erik Nord}

Professor i helseøkonomi, Universitetet i Oslo.

erik.nord@fhi.no mobil 95753201 www.eriknord.no

\section{$\underline{\text { Bakgrunn }}$}

Det er behov for bedre verktøy og prosesser for prioritering i helsevesenet.

Prioriteringsutvalgets utredning inneholder mye nyttig informasjon og resonnementer, og den er gjennomgående velskrevet. Men utvalgets arbeid er ensporet, og dets konkrete anbefalinger er verdimessig problematiske. Her er en implikasjon av anbefalingene:

En 40-åring og en 70-åring trenger en operasjon for hvert sitt problem. Problemene nedsetter livskvaliteten like mye. Begge får varig god effekt av operasjon. Prioriteringsutvalget vil legge vekt på at 40-åringen får glede av effekten i 40 år, mens 70-åringen får glede av den bare i 10 år. Utvalget vil videre legge vekt på at 40-åringen får et større helsetap enn 70 åringen hvis operasjon ikke gis, fordi han vil gå med problemet i 40 år i stedet for 10. Det foreslås mao en form for dobbeltregning av alder. I sum anser utvalget at operasjonen for 40åringen forsvarer anslagsvis en 6 ganger så høy kostnad som operasjonen for 70-åringen. Utvalget mener også at i en operasjonskø bør 40-åringer med moderate problemer prioriteres framfor 70-åringer med alvorlige problemer.

Disse og liknende implikasjoner av utvalgets forslag har ført til mange reaksjoner. I dette notatet forklarer og diskuterer jeg utvalgets forslag i detalj og anviser alternativ. Jeg retter kritikk mot utvalget for mangel på faglig grundighet og balanse i måten det har kommet fram til sine anbefalinger på. Er det feil i det jeg skriver, hører jeg gjerne om det.

Notatet gjelder utredningens kapitler om prioriteringskriterier. Det dekker ikke utredningens del 3 om 'prosesser og virkemidler'. 


\section{Innhold}

1 Sammendrag og anbefaling.

2 Nåværende versus foreslåtte nye prioriteringskriterier.

3 Eksempler på virkninger av eventuell overgang fra nåværende til nye prioriteringskriterier.

3.1 Vektlegging av helsegevinsters størrelse.

3.2 Prioritet til de dårligst stilte.

3.3 Dobbelt vekting etter alder mot hovedsakelig ingen vekting i dag.

4 Helsevesenets nåværende verdigrunnlag versus utvalgets tenkemåte.

5 Operasjonalisering av nåværende prioriteringskriterier som alternativ til utvalgets forslag.

6 Faglige innvendinger mot utvalgets prioriteringer, arbeidsmetoder og analyser.

6.1 Ubesvarte punkter i mandatet.

6.2 Manglende verdidiskusjon og etiske begrunnelser.

6.3 Uklart helsegevinstbegrep.

6.4 Ukritisk bruk av litteraturreferanser i forbindelse med vekting etter helsetap.

6.5 Uklart om helsetapsklasse null.

6.6 Trolig feilaktig anslag for helsetap hos de som får QALY på marginen.

6.7 Mangelfull drøfting av verdien av kortvarige livsforlengelser.

6.8 Ufullstendig drøfting av økonomiske virkninger utenfor helsesektoren.

6.9 Mangelfull drøfting av forskjell mellom statistiske og identifiserbare personer.

6.10 Mangelfull drøfting av diskontering av helsegevinster.

6.11 Manglende bruk av evidens ved forslag til gradering av betalingsvillighet.

6.12 Ufullstendig vurdering av eventuell spesialbehandling av sjeldne sykdommer.

6.13 Ingen vurdering av betalingsvillighet overfor dem som ikke kan klare seg selv.

6.14 Manglende vurdering av mening med og bruk av QALY.

6.15 Problem med bruk av grenseverdier når tiltak gir mange QALY per person.

7 Tendensiøse vurderinger som følge av forhåndsbestemte konklusjoner.

Vedlegg: Gradering av grenseverdier for en QALY. 


\section{Sammendrag: Hovedproblemer og anbefaling}

\section{Hovedproblemer}

Utvalget har ikke oppfylt mandatets punkt 2, hvor det ble bedt om å vise hvordan nåværende prioriteringskriterier kan konkretiseres. Det har gått rett løs på å beskrive et nytt sett av prioriteringskriterier som bygger på et litt annet verdisyn enn det som i dag gjelder i helsevesenet, som sentrale personer i utvalget og dets sekretariat har argumentert for i noen år (1-3).

Resultatet er at utredningen ikke inneholder en balansert framstilling av alternative handlingsmuligheter for politikerne. Kun ett alternativ foreligger til vurdering.

I følge dette alternativet skal helsevesenet gå lenger enn det gjør i dag mht til å prioritere de som har stor effekt av behandling framfor de som har vesentlig, men ikke så stor effekt, og de som har muligheter for å nå et høyt funksjonsnivå framfor de som ikke har muligheter til å nå et så høyt nivå.

Det skal også gis lavere prioritet jo færre år man har igjen av livet når sykdom rammer, dvs lavere prioritet med stigende alder.

Den etiske begrunnelsen for det foreslåtte alternativet, og diskusjon om mulige problematiske implikasjoner, er så godt som fraværende i utredningen, og bruk av kilder og evidens er selektiv, lite grundig, ukritisk og ubalansert.

\section{Anbefaling}

I debatt om prioritering må det være grunnleggende å starte med et skille som Prioriteringsutvalget glemte, nemlig det som går mellom forebyggende arbeid og behandling. I forebyggende arbeid er det rimelig å fremme (a) totalhelsen i befolkningen og (b) likhet mellom individer og grupper i forventet helse over levetida. Det gjør QALY-maksimering og helsetapskriteriet interessant. I beslutninger om behandlingskapasitet (inklusive legemiddelrefusjon) og prioritering mellom enkeltpasienter er det sterk tradisjon for (a) å gi prioritet til de med størst aktuelle behov og (b) sikre lik adgang for personer med samme grad av aktuelle behov. QALY-maksimering og helsetapsvurderinger over hele livsløpet er mindre passende i disse sammenhengene.

Helse- og omsorgsdepartementet bør sørge for at det blir lagt fram forslag til presisering og operasjonalisering av nåværende prioriteringskriterier. Datamessig og teknisk er dette kanskje vel så enkelt å få til som det forslaget Prioriteringsutvalget har lagt fram. En konkretisering og operasjonalisering av nåværende kriterier vil også være lettere å forstå for brukere. Sist, men ikke minst, vil det være mer i samsvar med nåværende verdier i norsk helsetjeneste.

Så kan det etter hvert føres en informert politisk debatt om to alternative sett av kriterier basert på to ganske forskjellige verdisyn, der kriteriene i begge settene er like klart definert og like operasjonaliserbare. 


\section{Nåværende versus foreslåtte nye prioriteringskriterier}

Ved prioritering i helsevesenet i dag vektlegges følgende:

a. tilstandens alvorlighet,

b. behandlingens nytte og

c. at behandlingskostnaden er 'rimelig' i forhold til alvorlighet og nytte, mens

d. alder i prinsippet ikke skal vektlegges med mindre den betyr noe for behandlingens sjanse for å være vellykket.

(Formelt er nåværende kriterium c 'kostnadseffektivitet' (formulert av Lønning II), men det reelle innholdet er det som er anført ovenfor.)

Prioriteringsutvalget foreslår å erstatte ovenstående kriterier med følgende:

e. pasientens beregnede helsetap, dvs tap av QALY, over hele levetida fram til 80 år hvis den behandlingen som vurderes ikke iverksettes,

f. helsegevinst av behandlingen målt i QALY, og

g. ressursbruk.

I pkt e omfatter helsetap også helsetap hittil i livet, og det omfatter alle former for helsetap pasienten har, dvs også tap som er forårsaket av andre sykdommer enn den som behandling vurderes for. Mer om dette nedenfor.

Utvalget mener at analyser og overveielser basert på disse kriteriene bør gjøres på alle beslutningsnivåer i helsevesenet, inklusive når almenpraktikere og sykehusleger treffer beslutninger på vegne av pasienter de har til utredning og behandling. 


\section{Konsekvenser ved eventuell overgang fra gamle til nye kriterier}

\subsection{Rimelig nytte av behandling versus maksimering av helsegevinster målt i QALY}

Utvalget er svært tydelig på at prioritet på alle beslutningsnivåer i helsevesenet skal øke med forventet helsegevinst regnet i QALY - uten forbehold eller avgrensning (2.2.2, 7.3 og kapittel 9).

En allerede mye omtalt implikasjon er at for tiltak med varig effekt (f.eks. kirurgi) vil prioritet være lavere desto færre leveår målgruppen har igjen, dvs desto eldre den er, alt annet likt. Nåværende kriterier åpner bare i begrenset grad for dette. Det er riktignok slik at QALY brukes i kostnad-effektberegninger i vurderinger av medisinsk teknologi (inklusive legemidler) allerede i dag, og beregning av helsegevinster i QALY trekker i retning av favorisering av yngre når det er tiltak med varig effekt som evalueres. Men denne faktiske bruken av QALY i dag er problematisk gitt gjeldende vedtatte prioriteringskriterier.

En annen implikasjon er at pasienter med sykdom som det kan gjøres mye med, skal ha prioritet framfor pasienter med sykdom som det kan gjøres noe vesentlig med, men ikke så mye. Behandlingens nytte vektlegges også i helsetjenesten i dag, men f.eks. i sykehus skiller man ikke etter behandlingseffektens størrelse så lenge den er vesentlig.

En tredje implikasjon, knyttet til bruken av QALY, er at behandling som vinner leveår anses å være mer verdifull hvis den gjelder personer med god helsestatus for øvrig enn hvis den gjelder personer med kronisk sykdom eller funksjonshemming. F.eks. skal et tiltak som avverger død blant personer med alvorlig astma ha lavere prioritet (møte lavere betalingsvillighet) enn tiltak som kurerer kreft og derved vinner like mange leveår blant ellers friske mennesker. Denne forskjellsbehandlingen er i dag ikke tilstede på sykehus, og det er økende oppmerksomhet om dens problematiske side ved Legemiddelverket, der QALY brukes systematisk i evaluering av medisiner for eventuell opptak i blåreseptordningen.

\subsection{Vekting av helsegevinster etter alvorlighet versus vekting etter helsetap over levetida}

Det er alminnelig enighet om at de som er helsemessig dårligst stilt, fortjener prioritet når ressursene er begrenset, og at det offentliges betalingsvillighet for helsegevinster bør være større jo dårligere stilt mottakerne er i utgangspunktet. Spørsmålet er hva som skal anses å være relevant når man vurderer hvor dårlig stilt en person er. I dag er det 'tilstandens alvorlighet' som anses relevant. Utvalget foreslår at det i stedet skal være 'pasientens samlede helsetap over livet’. Det behøver strengt tatt ikke være et enten eller. Selv om alvorlighet utvilsomt veier tungt i medisinsk tradisjon og i helsepolitikk, er det ikke urimelig å tenke seg at vurdering av helsetap over livet kunne være et tilleggshensyn i noen prioriteringssammenhenger. Det gjelder åpenbart i folkehelsearbeid (forebyggende arbeid), 
men kan også i noen grad være tilfelle i andre sammenhenger. Prioriteringsutvalget foreslår imidlertid å erstatte alvorlighetskriteriet med kriteriet 'helsetap over livet’. Da må man stille dem opp mot hverandre og sammenlikne.

Utvalget hevder, og utvalgets leder har siden gjentatt flere ganger i massemedier, at alvorlighetsbegrepet er vanskelig å forstå og vanskelig å måle og at helsetapsbegrepet er enklere. Det er uriktig. Begge begrepene har en klar operasjonell definisjon. Det er verdigrunnlagene og de praktiske implikasjonene som er forskjellige.

Med alvorlighet menes for det første hvor ille tilstanden er på vurderingstidspunktet ('alvorlighet i øyeblikket'). Dette kan uttrykkes som tap av livskvalitet på 0-1 skalaen som brukes i QALY-beregninger. For det andre menes med alvorlighet hvor mye livskvalitet og/eller leveår som forventes tapt i framtida hvis den behandlingen som vurderes, ikke iverksettes ('alvorlighet over tid'). For å unngå å blande alvorlighetsbegrepet sammen med alder, kan alvorlighet over tid måles som 'relativt framtidig helsetap'. Man anslår hvor mange QALY personer i pasientens aldersgruppe normalt har igjen ( = A) og hvor mange QALY pasienter med den aktuelle tilstanden må forventes å miste $(=\mathrm{B})$ hvis den behandlingen som vurderes, ikke iverksettes. Alvorligheten over tid beregnes som tapet B $i$ prosent av A.

Helsetap over levetida, som Prioriteringsutvalget fokuserer på, beregnes ved å summere eventuelle QALY pasienten har tapt i leveårene forut for det tidspunktet da behandling for en bestemt sykdom vurderes (= C), og QALY som forventes tapt i gjenstående levetid hvis den behandlingen som vurderes, ikke iverksettes (samme som tapet B ovenfor). Merk at både helsetap knyttet til den aktuelle sykdommen og helsetap forårsaket av andre sykdommer eller funksjonsnedsettelser som pasienten har eller har levd med, regnes med i helsetap over levetida, se nedenfor.

Nedenfor er eksempler på beslutningssituasjoner hvor vektlegging av henholdsvis alvorlighet og helsetap over levetida slår ut forskjellig. Jeg skiller mellom når sykdom inntreffer og når nye behandlingsmetoder kommer (herunder legemidler). Jeg skiller også mellom kontinuerlig behandling (f.eks. legemidler for kronikere) og behandling med varig effekt (f.eks. kirurgi). Jeg forutsetter hele tiden at normal livslengde er 80 år.

\subsubsection{Når sykdom inntreffer}

Kontinuerlig behandling: Hansen (70) og Olsen (50) har fått hvert sitt smerteproblem som vil være kronisk uten løpende behandling med legemiddel. For begge reduseres livskvaliteten med 0,2 poeng på en skala fra 0 (død) til 1 (frisk) som brukes i QALY-beregninger. De har samme alvorlighet både i øyeblikket og regnet over tid (20 prosent), men Olsen har større helsetap uten behandling (0,2 i 30 år = 6 QALY mot Hansens 0,2 i 10 år = 2 QALY). Effekten av behandling på livskvalitet er den samme. I dag prioriteres de likt. Etter utvalgets forslag skal Olsen (som er yngre) prioriteres. Han skal også prioriteres selv om Hansen skulle ha noe sterkere smerter. 
Behandling med varig effekt. Hansen (70) og Olsen (50) har fått hver sin type kreft og forventes å leve hhv 4 og 12 år til. Olsen har større helsetap enn Hansen - 18 mot 6 leveår, men de har samme alvorlighet regnet prosentvis over tid, hhv 6/10x100 $=60$ prosent og 18/30x100 = 60 prosent. Alvorlighet i øyeblikket kan trolig også sees som nokså lik. Operasjon kan øke forventet levetid like mye. I dag prioriteres de likt. Etter utvalgets forslag skal Olsen (som er yngre) prioriteres.

Behandling med varig effekt, eksempel 2. Hansen (70) og Olsen (60) har fått samme type kreft, og begge forventes å leve 4 år til. Operasjon kan øke forventet levetid like mye. Olsen har større helsetap enn Hansen - 16 år mot 6 år. Alvorlighet over tid er 16/20x100 = 80 prosent for Olsen og 6/10x100 = 60 prosent for Hansen. Etter begge kriterier skal Olsen ha prioritet. På den annen side kan alvorlighet i øyeblikket kanskje sees som nokså lik. I norsk helsetjeneste i dag varierer det antakelig mht om Olsen får prioritet foran Hansen.

Samtidig annen sykdom eller funksjonshemming. Hansen (60) kan gå, mens Olsen (60) er rullestolbruker. De henvises for samme problem, og begge kan hjelpes like mye. I dag prioriteres de likt, fordi det aktuelle problemet er like alvorlig. Etter utvalgets forslag skal Olsen ha prioritet (side 138, annen spalte første avsnitt og side 199) fordi han har større samlet helsetap over livet.

Tidligere helsetap. Hansen (60) og Olsen (60) henvises for like alvorlige problemer og kan hjelpes like mye med en ny behandlingsmetode. Olsen har hatt problemet i 40 år, Hansen i 10 år. I dag prioriteres de likt, i det tidligere helsetap ikke anses relevant og ikke inngår i alvorlighetsbegrepet. Det er 'her og nå' og tida framover som teller. Etter utvalgets forslag skal Olsen prioriteres fordi hans samlede helsetap over livet er større (side 197, annen spalte, første avsnitt).

\subsubsection{Når nye behandlinger kommer}

Kontinuerlig behandling. Det søkes om opptak i blåreseptordningen av to nye legemidler, L50 og L70, for to forskjellige pasientgrupper. L50 gjelder pasienter med median alder omkring 50, mens L70 gjelder andre pasienter med median alder omkring 70. De to gruppene har samme livskvalitet gitt dagens standardbehandling for hver av dem. De to nye legemidlene gir begge en symptomdemping tilsvarende 0,1 QALY per år per pasient i forhold til dagens standardbehandling, til en pris av 40.000 kroner i året. Siden de to gruppene har samme alvorlighet og legemidlene har samme kostnad per QALY, vil de to legemidlene i dag møte lik betalingsvillighet fra det offentliges side. Etter utvalgets forslag skal L50 prioriteres. Det kan bety at de som trenger L50 får det dekket av det offentlige, mens de som trenger L70 ikke får det dekket av det offentlige, på grunn av aldersforskjellen.

Kontinuerlig behandling, samtidig annen sykdom. Det søkes om opptak i blåreseptordningen av to nye legemidler, L1 og L2, for to forskjellige sykdommer. Pasientgruppene er jevngamle. De to gruppene har samme grad av plager fra sine respektive sykdommer gitt dagens standardbehandling for hver av dem. Men i gruppe 1 er det vanlig at man også har en annen 
lidelse eller funksjonshemming. De to nye legemidlene gir begge en symptomdemping tilsvarende 0,1 QALY per år per pasient i forhold til dagens standardbehandling, til en pris av 40.000 kroner i året. Siden de to gruppene har sykdommer med samme alvorlighet (grad av plager) og legemidlene har samme kostnad per QALY, vil de to legemidlene i dag møte lik betalingsvillighet fra det offentliges side. Etter utvalgets forslag skal L1 prioriteres, fordi målgruppens samlede helsetap over livet er større. Det kan bety at de som trenger L1 får det dekket av det offentlige, mens de som trenger L2 ikke får det dekket av det offentlige, fordi de er friske forøvrig .

\subsection{Dobbelt vekting etter alder mot i hovedsak ingen vekting i dag}

Utvalget skriver i pkt 8.1.2 og utvalgsleder hevder i ettertid at det ikke foreslås at alder skal være et direkte prioriteringshensyn. Dette er ikke riktig. Anta at en 50-åring får en kronisk sykdom. Når man tar utgangspunkt i en normal levealder på 80 år, blir helsetapet i følge utvalget 80-50 multiplisert med det årlige livskvalitetstapet. Sett inn alder 60 i stedet for 50 , og helsetapet - og dermed prioriteten - går ned. Dette er direkte effekt av alder. Hvis tiltaket er med varig effekt, f.eks. en operasjon, blir helsegevinsten for femtiåringen 80-50 multiplisert med livskvalitetsgevinsten. Sett in alder 60 i stedet for 50, og helsegevinsten - og dermed prioriteten - går ned. Også det er direkte effekt av alder. Samlet sett dobbeltregnes alder i dette eksemplet, i betydningen at alder slår ut via både helsetapskriteriet og helsegevinstkriteriet.

Til sammenlikning vil det etter dagens kriterier vil det vanligvis ikke være noen prioritetsforskjell mellom 50- og 60-åringer i en operasjonskø.

Hvis behandling er kontinuerlig (f.eks. medisinering for kronikere), regnes helsegevinster og ressursbruk for det enkelte år. Forskjeller i gjenstående levetid slår da ikke ut på forholdet mellom helsegevinst og ressursbruk. Dvs at alder i denne situasjonen ikke øker prioritet gjennom helsegevinstkriteriet. Men den gjør det fortsatt gjennom helsetapskriteriet. 


\section{Utvalgets tenkemåte og en alternativ tenkemåte}

Utvalget tenker for det første at det i behandlingsapparatet i helsevesenet gjelder å skape mest mulig helse med de midler man har til rådighet. Tenkemåten er hentet fra vanlig produksjonsvirksomhet. Ta f.eks. en bonde som ikke har tid til å dyrke opp all jorden sin. Han begynner med den åkerlappen hvor jorda er best. Så går han løs på den nest beste åkerlappen, osv. Slik får han mest igjen for sin knappe tid. Mange helseøkonomer har i mange år tenkt tilsvarende om helsetjenesten: Man bør prioritere de pasientene som har størst effekt av behandling, dernest de med litt mindre effekt osv. Utvalget vil gå lenger i denne retningen enn man hittil har gjort.

Utvalget mener for det andre at det å skape mest mulig helse må modifiseres med at helsegevinster bør tillegges større vekt (verdi) jo dårligere stilt mottakerne av gevinstene (pasientene) er i utgangspunktet. Utvalget mener at samlet helsetap over livet er et etisk mer relevant mål på hvor dårlig stilt man er enn tilstandens alvorlighet i øyeblikket og over tid framover (min velvillige tolkning, utvalget sier det ikke direkte, se nedenfor under avsnittet 'Manglende verdidiskusjon og etiske begrunnelser').

Jeg tror for det første at utvalget er i konflikt med det helsevesenets eiere - dvs folk flest mener er helsevesenets oppgave. De ser ikke på helsevesenet som en produksjonsbedrift som skal maksimere et eller annet, men som et solidaritetsprosjekt. De aksepterer at helsevesenet ikke skal drive med ting som ikke virker. Men de forventer at helsevesenet skal møte folk etter graden av behov de har når de blir syke eller skadet eller får funksjonstap og prøve å gjøre det best mulige for hver enkelt innenfor rimelighetens grenser (dvs når det gjelder ressursbruk). De forventer lik adgang ved samme grad av alvorlighet så lenge helsehjelpen vil være til vesentlig nytte, og de forventer at alder ikke skal bety noe bortsett fra i visse tilfeller. Unntakstilfellene omfatter situasjoner der høy alder vesentlig reduserer sjansene for at behandling virker, situasjoner der målgruppen er barn og situasjoner der pasientene er svært gamle og det er spørsmål om kostbare livsforlengende behandlinger. Ingen klager over at det i dag i hovedsak ikke foregår forskjellsbehandling etter alder utover dette. Eldre voksne reagerer forståelig nok sterkt på et forslag om at når de kommer til den fasen i livet hvor sykdom blir mer og mer vanlig, skal de prioriteres ned i forhold til yngre voksne. Det er egentlig en paradoksal tanke.

Jeg tror for det andre at utvalget overser en elementær psykologisk mekanisme knyttet til menneskelig lidelse og livsfare. Jo mer alvorlige, akutte og synlige de er, og jo mer de er knyttet til konkrete enkeltpersoner vi har framfor oss, desto sterkere føler vi en moralsk forpliktelse til å hjelpe uten tanke på kostnader. Arbeidere innesperret i en gruve og barnet falt ned i en brønn er klassiske eksempler på hendelser som gjør helseøkonomi helt uaktuelt. I motsatt ende av skalaen er befolkningsrettede tiltak av forebyggende karakter. Det er ingen identifiserbare personer som krever oss, og vi kan tillate oss å være mer kjølig vurderende, herunder å tenke 'høyest mulig helse for folket som helhet', herunder å prioritere tiltak blant unge med mangeårig effekt. Mellom disse ytterpunktene er det grader av følelse av 
forpliktelse. Helsebyråkrater og politikere bestemmer uten store kvaler på hvilke områder behandlingskapasitet skal økes og hvilke i og for seg utmerkede tiltak det må sies nei til på årets budsjett. Pasientene sitter ikke på den andre siden av skrivebordene. I almenpraksis og på sykehus, derimot, møter leger og sykepleiere i tur og orden konkrete pasienter med synlige hjelpebehov, som de i noen grad får en personlig relasjon til og medfølelse med. Gitt den sistnevnte psykologiske rammen forbauses jeg i utredningens kapittel 9.3.1 og 9.3.2 over hvor $ø$ konomisk-rasjonelt og nøkternt vurderende utvalget mener at leger skal opptre og hvor langt de skal praktisere QALY-maksimering og teoretiske betraktninger om helsetap over livet i sine beslutninger. Almenleger skal f.eks. ha lavere henvisningsterskel for yngre enn for eldre voksne, og tilsvarende aldersmessig forskjellsbehandling foreslås for sykehuslegers beslutninger om innlegging på intensivavdeling. Det virker som om Prioriteringsutvalget har falt for en teoretisk, akademisk tankegang.

\section{Et alternativ til utvalgets forslag: Operasjonalisering av nåværende prioriteringskriterier}

Utvalget får ros bl.a. fra klinikere for å ha laget mer konkrete og presise prioriteringsverktøy enn de vi har i dag. Men konkretisering og presisering fordrer ikke endring av helsevesenets verdigrunnlag. Det har i 15-20 år foreligget konkrete verktøy til bruk for prioritering i samsvar med gjeldende kriterier (4,5). De har bare ikke blitt finslipt og tatt i bruk. De innebærer at:

- verdien av helsegevinster øker med økende alvorlighetsgrad (i øyeblikket og over tid framover),

- verdien av tiltak for ulike pasientgrupper ikke regnes som proporsjonal med effektstørrelse, men bestemmes av om det blir gjort noe vesentlig for mottakerne og i hvilken grad deres potensial for helse blir realisert,

- verdien av vunne leveår regnes som den samme når årene oppnås hos personer med funksjonshemming eller kronisk sykdom som når de oppnås hos personer som vinner år uten helseproblemer,

- alder bare unntaksvis får betydning for verdsettingen av helsegevinster.

Metodene er basert på omfattende innsamling av data om befolkningens preferanser $\mathrm{i}$ prioriteringsspørsmål og er utførlig beskrevet i litteraturen, se for eksempel referansene 6 og 7 til slutt i dette notatet. Metodene er helt ignorert av Prioriteringsutvalget. De innebærer en gradering av betalingsvillighet for 'gode leveår' på et større presisjonsnivå enn det utvalget foreslår på side 128. Kriteriene for gradering er slik at den i hovedsak gir lik betalingsvillighet for ulike aldersgrupper. I vedlegg til dette notatet sammenliknes utvalgets forslag med en tabell med en evidensbasert plausibel gradering etter alvorlighetsgrad.

En fordel med ovenstående alternativ er at kriteriene alvorlighet og alder holdes fra hverandre. I utvalgets helsetapskriterium slås disse sammen. Det innebærer at man mister en frihetsgrad i bestemming av prioritet. Om man f.eks. mener at en dobling av alvorlighet skal 
bety mer enn en dobling av gjenstående levetid, vil dette ikke fanges opp av helsetapskriteriet, der alvorlighet og alder automatisk får nøyaktig samme vektlegging. Med alternativet ovenfor kan en holde fast ved hovedlinjene i dagens prioriteringsetikk og eventuelt bestemme seg for å supplere med aldersvurderinger i akkurat den grad man finner forsvarlig. Dette er elementær matematisk logikk, som det er overraskende at utvalgets økonomer ikke har vurdert.

\section{Faglige innvendinger mot utvalgets prioriteringer, arbeidsmetoder og analyser}

\subsection{Ubesvarte punkter i mandatet}

Dagens prioriteringer i helsevesenet går som foran nevnt ut på å vektlegge følgende:

a. tilstandens alvorlighet,

b. behandlingens nytte og

c. at behandlingskostnaden er 'rimelig' i forhold til alvorlighet og nytte, mens

d. alder i prinsippet ikke skal vektlegges med mindre den betyr noe for behandlingens sjanse for å være vellykket.

Grovt sett kan det skilles mellom to mulige utredningsoppgaver: (A) å presisere disse kriteriene for at de skal virke bedre og (B) å stille opp et litt annet sett av kriterier. Det første er å holde fast ved de underliggende verdiene, det andre er å modifisere verdigrunnlaget. Det er rimelig å tolke mandatets pkt 2a underpunkt i-iii som at utvalget skulle utføre oppgave A (å vurdere hvordan nåværende kriterier kan presiseres for at det skal virke bedre). Det skulle videre vurdere om 'også andre kriterier skal legges til grunn', altså gå inn på oppgave B. Oppgave A er ikke utført. Utvalget går rett løs på oppgave B (nytt kriteriesett), se side 12, første spalte, tredje og fjerde avsnitt, og avsnitt 7.1 og 7.2. Det betyr særlig:

- $\quad$ Det er ikke vurdert hvordan dagens alvorlighetskriterium kan konkretiseres/operasjonaliseres/kvantifiseres. Måter dette faktisk gjøres på i dag, er så bare såvidt nevnt i stikkords form og overhodet ikke forklart.

- Det er ikke diskutert hvordan 'nytte' kan presiseres, herunder hva subjektiv nytte/verdi av helsehjelp er for de som får den til forskjell fra objektiv medisinsk effektstørrelse.

- (Punkt om kortvarige livsforlengelser tatt ut.)

- $\quad$ Under mandatets punkt om nyttekriteriet har utvalget videre ignorert punkt 2a(ii)3 om å vurdere tanken i Lønning 1 om realiseringen av potensialer. Dette skjer til tross for at tanken også er anbefalt vurdert i en fersk WHO-publikasjon der utvalgets leder er førsteforfatter (8). 
I sum leverer utvalget ikke en utredning av to alternative politikkmuligheter, dvs presisering av nåværende kriterier innenfor gjeldende verdigrunnlag versus nye kriterier basert på delvis endret verdisyn. Oppdragsgiver får bare det sistnevnte.

\subsection{Manglende verdidiskusjon og etiske begrunnelser}

Hvis man vil erstatte eksisterende prioriterings kriterier med et modifisert sett, må det være fordi man mener det finnes relevante hensyn som de nåværende kriteriene ikke dekker og som de foreslåtte kriteriene fanger opp. Den naturlige framgangsmåten vil i så fall være først å anføre disse hensynene og begrunne dem etisk, og først deretter formulere et sett av operasjonelle kriterier som gjør at hensynene blir ivaretatt. Det er ikke tilfellet her:

Utvalget foreslår for det første å erstatte dagens norm om 'rimelig forhold mellom nytte og kostnader' med at ' jo høyere helsegevinstene er (målt i QALY), desto høyere prioritet' (se f.eks. pkt 2.2.2 og pkt 7.3, annet avsnitt). Dette er å vektlegge størrelsen av helsegevinsten ('helsemaksimering') mer gjennomført og konsekvent enn tilfellet er i dag. Det er ikke noe sted gitt noen etisk begrunnelse for dette. Det skulle bl.a. ha vært vurdert opp mot en alternativ tankegang - det å ville realisere potensialer, jfr ovenfor, slik mandatet forutsatte. Ingen slik diskusjon forekommer. Men man finner paradoksalt nok en liten bemerkning side 89 annen spalte annet avsnitt om at det 'ikke er rettferdig å se helt bort fra små gevinster til noen individer så lenge de oppleves som en positiv endring for dem'. Dette er et spesialtilfelle av nåværende tankegang. Men den forekommer bare som et isolert tilfelle.

Utvalget foreslår for det andre å erstatte dagens alvorlighetskriterium med et kriterium om samlet helsetap over livet. Det er ingen etisk argumentasjon eller begrunnelse for dette i utredningens hovedtekst. Først i vedlegg 4 side 196 står det noen få linjer om 'Generell begrunnelse for et livsløpsperspektiv'. Her står det at 'en hovedgrunn for å ta utgangspunkt i et livsløpsperspektiv er rett og slett at det er hele liv som grunnleggende betyr noe.' Det er et så godt som sirkulært utsagn og altså ingen begrunnelse. Utover dette er det svært lite utover referanser til visse teoretikere som er tilhengere av livsløpsperspektivet. Referansene er 'autoritetsbruk', ikke begrunnelser. Autoritetetene er i virkeligheten ikke autoriteter. Medisinske etikere er uenige. Man kan alltid finne noen som er enige med en selv. En av de refererte er en professor i helseøkonomi uten spesiell kompetanse i rettferdighetsteori. En annen referanse er til et arbeid fra doktoravhandlingen til den ene utvalgssekretæren (2).

$\AA ̊$ anføre grundige, holdbare, substansielle, moralske begrunnelser for standpunkter er kjernen i faget medisinsk etikk. Utvalget har ikke holdt seg til fagets idealer og kjerne.

\subsection{Uklart helsegevinstbegrep}

Utvalget vil erstatte begrepet 'nytte' med begrepet 'helsegevinst' fordi det mener det førstnevnte 'er vanskelig å forstå for mange’ (side 82, annen spalte, tredje avsnitt). Men utvalgets egen tekst er forvirrende. Det heter i første avsnitt i pkt 7.3 og 7.3.1 at velferd er noe 
annet enn helse, men at helsegevinst er det samme som velferdsgevinst. Velferd defineres som livskvalitet (første avsnitt i 7.3.1), mens velferdsgevinster defineres som både vunnet livskvalitet og vunnet levetid (siste avsnitt i 7.3.1). Pasienters livskvalitetsgevinster foreslås målt med et instrument som er kjent for å ikke fange opp pasienters egne opplevelser og vurderinger (EQ-5D). Når utvalget skriver at 'måling av helserelatert livskvalitet bør være basert på velinformerte preferanser' (s134, første spalte, tredje avsnitt), er det helt uklart i hvilken grad pasienter direkte skal involveres som subjekter i den datainnsamlingen som anbefales. I sum er det uklart hva utvalget dypest sett mener med 'jo større helsegevinst, desto høyere prioritet’. Er det objektiv helseeffekt eller subjektiv verdsetting av effekten som skal vektlegges? Dermed blir det også uklart hvor mye utvalgets tenkning avviker fra tanken om realisering av potensialer, som i høy grad dreier seg om å vektlegge at pasienter selv kan oppleve moderate forbedringer som viktige nok for dem.

\subsection{Ukritisk bruk av referanser i forbindelse med vekting etter helsetap over livet.}

Studiene nevnt nederst side 96, første spalte - Andersson \& Lyttken, Bleichrodt et al og Dolan og Tsuchyia - gjelder preferanser mellom sluttfordelinger av helse. Respondenter uttrykker for eksempel at de foretrekker et samfunn med 70 gode leveår til hver av gruppene A og B framfor et samfunn med 80 gode leveår til gruppe $\mathrm{A}$ og 65 til gruppe $\mathrm{B}$, altså en preferanse for likhet i helse. Det følger ikke av dette at respondentene mener at man bør fravike prinsippet om likebehandling av ulike aldersgrupper når pasienter melder seg med sine behov i helsetjenesten. Disse studienes relevans for bestemming av gradert betalingsvillighet for gode leveår er følgelig begrenset. Utvalget har ikke vurdert problemet.

\subsection{Uklart om helsetapsklasse null.}

På side 98 foreslås tre helsetapsklasser. På side 128 blir de til fire. Den nye klassen - klasse null - er uforklart. Utvalget opplyser i ettertid at klassen innebærer 'null helsetap'. Dvs at klasse 1 går ned til ytterst lite helsetap, la oss si 0.1 godt leveår. Det er umiddelbart ikke lett å forstå hvorfor det skal være en betalingsvillighet på opptil kr 250.000 for å vinne et godt leveår for personer som overhodet ikke har helsetap. Forklaringen viser seg å være at personer som får minst 80 gode leveår ikke har helsetap i utvalgets forstand, men fortsatt kan ha det i virkeligheten (f.eks. en hittil frisk 80-åring som blir syk) og fortsatt har rett til behandling (OF Norheim, epost 2. desember). I utredningen står det ingenting om dette.

\subsection{Regnefeil om helsetap knyttet til personer som mottar QALY 'på marginen'.}

På side 128, annet avsnitt heter det: '.. for endringer på marginen vil helsetapet (over livet for berørte pasienter) normalt være lite'. Dette stemmer ikke med opplysningen på side 93 om at gjennomsnittlig helsetap over livet er ca 12 gode leveår. For personer som rammes av sykdom i 60-70-årsalderen, er gjennomsnittlig helsetap over livet i størrelsesorden 8-10 gode leveår. 
Epostutveksling med utvalgsformannen har avklart at i utredningen er dette oversett. De gode leveår som ofres ved et tiltak må være assosiert med et (normalt) helsetap på 8-10 + det særlige tapet som følger av sykdommen som tiltaket gjelder.

Det virker heller ikke rimelig at det særlige tapet skal være ned mot 'nedre del av helseklasse 1' (1-2 gode leveår) som utvalget hevder s128, første spalte, midt på siden. Det er lett å tenke seg at på marginen rekker mange gode tiltak for kronikere innenfor både somatikk, psykiatri og rus ikke opp. Der er det betydelige helsetap over livet. Det er utilfredsstillende at utvalget ikke har brukt et minimum av plass til å resonnere omkring dette og i stedet nøyer seg med to setninger som fører fram til en enkel og bekvem forankring av deres trappetrinnmodell.

I sum virker det mer plausibelt at gode leveår som ofres på marginen er assosiert med et helsetap på 12-20 gode leveår, i stedet for 'tap i nedre del av helsetapsklasse 1' (1-2 gode leveår). Legges dette til grunn, blir grenser for betalingsvillighet liggende en god del lavere enn det utvalget har foreslått i figur 9.1, se vedlegg.

Dette betyr også at helsetap for sykdommene nederst i figur 10.1 side 138 virker for lavt anslått (f.eks. 11 tapte gode leveår for atrieflimmer).

\subsection{Mangelfull drøfting av verdien av kortvarige livsforlengelser.}

Dette har vært et hovedtema i de seinere års debatt om prioritering, og tanken har vært lansert, bl.a. for Nasjonalt råd for prioritering, at man kanskje skulle være villig til å si at å trekke ut livet for terminalt syke med noen få måneder har liten hensikt og at QALYs oppnådd i en slik kontekst må anses å være mindre viktige enn QALYs knyttet til at man gir pasienter et vesentlig antall ekstra leveår. Problemstillingen er avspist uten diskusjon og begrunnelse med en liten tekstboks på side 133. I punkt 11.3 er det en god diskusjon av ønskelige prosesser i livets sluttfase, men tanken om lavere betalingsvillighet for QALYs i denne konteksten blir aldri berørt.

\subsection{Ufullstendig drøfting av relevansen av økonomiske virkninger utenfor helsesektoren.}

Det anføres rettferdighetsgrunner for å ikke inkludere produksjonsgevinster ved behandling. Men helt tilsvarende rettferdighetsgrunner kan anføres for ikke å prioritere pasienter med stort potensial for funksjonsforbedring framfor pasienter med mer moderat potensial, eller ikke å prioritere pasienter som er billige å behandle framfor pasienter som er dyre å behandle. Det mangler konsistens, i betydningen konsekvent gjennomføring av rettferdighetsargumentasjonen, i vurderingen av ulike effektivitetshensyn.

Videre er levekostnader knyttet til vunne leveår ikke diskutert. De kommer i tillegg til behandlingskostnadene.. Å inkludere slike kostnader vil gjøre livkvalitetsforbedrende tiltak mer prioriteringsverdige i forhold til livsforlengende tiltak. Det er neppe grunn til å holde slik 
kostnader utenfor av rettferdighetshensyn, siden alle som vinner leveår har slike kostnader. Temaet er ikke diskutert.

\subsection{Mangelfull drøfting av forskjell mellom statistiske og identifiserbare personer.}

Side 117, tredje avsnitt: Dette er svært kort og ubegrunnet. Daniels (2012), som er referert, fant ikke etiske grunner til forskjellsbehandling, men samfunnspsykologiske forhold kan likevel tilsi at forskjellsbehandling er rimelig. Utvalget burde ha diskuterte dette, i stedet for bare å erklære at ‘det er vanskelig å finne grunner til ulik vektlegging...' .

\subsection{Mangelfull drøfting av diskontering av helsegevinster.}

Side 136-7: Dette er svært kort og dårlig begrunnet. Det er mindre uenighet om dette i dag enn man gir inntrykk av (jfr artikler av bl.a. van Hout/Brouwer/Nord/Claxton mfl), og det virker rart at utvalget ikke trekker inn norske arbeider om dette i de seinere år, herunder empiriske undersøkelser av tidspreferanser blant et betydelig antall personer i norsk helsepolitikk og helseforvaltning (9).

\subsection{Manglende bruk av relevant kilde som grunnlag for forslag til helsetapsavhengige grenser for betalingsvillighet.}

På side 99, første spalte, annet avsnitt er det vist til Andersson\&Lyttken, Bleichrodt et al og Dolan og Tsuchyia. Som påpekt ovenfor gjelder disse preferanser mellom sluttfordelinger av helse. Deres relevans for prioritering av behandling i helsetjenesten er ikke vurdert. Ottersen et al (2014), som er nevnt, har et alvorlig metodeproblem, i det spørsmålet til subjekter var slik at svarene like gjerne kunne tolkes som vektlegging av alvorlighet over tid som vektlegging av helsetap over livet. En systematisk review (6) som direkte belyser betalingsvillighet for en QALY avhengig av alvorlighet, ble sendt utvalget til hjelp. Den er ikke nevnt. I vedlegget til dette notatet er det vist hvordan den sistnevnte studien direkte kunne ha belyst rimeligheten av utvalgets foreslåtte grenseverdier.

\subsection{Ufullstendig vurdering av mulige grunner til eventuell spesialbehandling av sjeldne sykdommer.}

Avsnitt 8.4 er i hovedsak grundig og informativt, men det finnes etiske argumenter som ikke er nevnt, herunder at 'deling av goder' av de fleste oppfattes som et gode i seg selv, og at det at noen får svært lite eller ikke får noe i det hele tatt, oppfattes som et onde (10). Personer med sjeldne sykdommer er også dårligere stilt enn andre i den forstand at de til enhver tid har mindre håp om at framtida skal bringe dem bedre medisiner, og det å være dårlig stilt er et 
argument for prioritet. Dette kan være moralske argumenter for særbehandling av sjeldne sykdommer. Tyngden av dem må vurderes nærmere.

\subsection{Manglende vurdering av betalingsvillighet for omsorg for de som ikke kan klare seg} selv.

I notat og presentasjoner for Nasjonalt råd for prioritering foreslo jeg i fjor å skille mellom noen hovedtyper av tiltak når en vurderer grenser for betalingsvillighet. En hovedtype er omsorg for mennesker som ikke klarer seg selv (psykiatri, HVPU, syke gamle). Her kan neppe vanlige tanker om betalingsvillighetens grenser gjelde. Inndelingen i hovedtyper ble oppfattet som fruktbar i Rådet. Utvalget bruker den ikke og har så vidt jeg har kunnet se ikke drøftet omsorgskategorien.

\subsection{Bruk av QALY.}

Side 133-4: Det mangler drøfting av hva QALY egentlig måler (effektstørrelse, nytte eller pasienters faktiske velferdsgevinst), og, som nevnt ovenfor, når utvalget skriver at 'måling av helserelatert livskvalitet bør være basert på velinformerte preferanser’ (s134, første spalte, tredje avsnitt), er det helt uklart i hvilken grad pasienter direkte skal involveres som subjekter i den datainnsamlingen som anbefales. Den diskriminerende virkningen av QALY ved livsforlengende behandlinger (se pkt 3.1 ovenfor, tredje implikasjon) bør være meget kjent for flere i utvalget og sekretariatet, men er overhodet ikke diskutert.

\subsection{Problem med grenseverdier når tiltak gir mange QALY per person.}

Grenseverdier for en QALY blir mest diskutert i forbindelse kortvarige livsforlengelser eller løpende behandling, for eksempel legemidler som pasientene står på permanent. Man ser da på helsegevinst og kostnad i det enkelte leveår. Man finner for eksempel at et legemiddel gir en livskvalitetsforbedring på 0,2, hvilket gir 0,2 QALY per år, og bestemmer at legemidlet forsvarer en kostnad på inntil 100.000 kroner per år (gitt grense på for eksempel kr 500.000 per QALY). Så aksepterer man eventuelt å bruke 100.000 år etter år på pasienter som trenger dette legemidlet. Men anta i stedet en operasjon som redder liv og vinner 30 leveår, dvs 30 QALY. Skal det offentlige være villig til å betale inntil 15 millioner kroner for denne operasjonen (gitt grenseverdien på kr 500.000 per QALY)? Det virker ikke realistisk. Engangstiltak som gir mange vunne leveår synes å kreve egne grenseverdier. Dette er ikke vurdert av utvalget. Et litt kryptisk avsnitt nederst side 98 handler om noe annet. 


\section{Tendensiøse vurderinger som følge av forhåndsbestemt konklusjon.}

Manglende sammenlikning av alternative muligheter, og manglende utøvelse av kjernen i faget medisinsk etikk (å gi etiske begrunnelser for et nytt sett av prioriteringskriterier), tyder på at det forelå klare personlige forhåndsoppfatninger om hva som burde komme ut av utvalgets arbeid. Dette stemmer med det som er blitt resultatet. Utredningen handler om å forklare og forsvare én bestemt løsning. Det er ukritisk bruk av kilder og fakta som støtter utvalgets forslag og utelatelse av kilder og fakta som ville ha gjort det motsatte.

Et tydelig eksempel er omtalen av dagens alvorlighetskriterium. Det heter at 'helsetapskriteriet er spesifikt på mange områder der alvorlighetskriteriet ikke gir konkret veiledning’ (side 95 øverst i annen spalte). Dette er basert på en sammenlikning av et operasjonalisert helsetapskriterium med et ikke-operasjonalisert alvorlighetskriterium - altså ikke en sammenlikning like for like. I operasjonalisert form (forklart nedenfor) er alvorlighetskriteriet akkurat like spesifikt og veiledende som helsetapskriteriet.. Utvalget vet det egentlig, for operasjonaliseringen nevnes i forbifarten øverst side 75, første spalte og så vidt i vedlegg 4, side 198 avsnitt 5, og utvalgets leder har selv brukt konkretiseringen i publikasjoner (11). Men i utredningen sies det om konkretiseringen bare at 'det oppstår flere utfordringer’ (s 198), uten at man noen gang får vite noe om disse.

Enda alvorligere er sammenlikningen av de to kriteriene helsetap og alvorlighet i forbindelse med forebyggende tiltak (side 124, første spalte, andre og tredje avsnitt). Det velges en bestemt forståelse av alvorlighetskriteriet, nemlig som gjeldende målpersonens tilstand ved

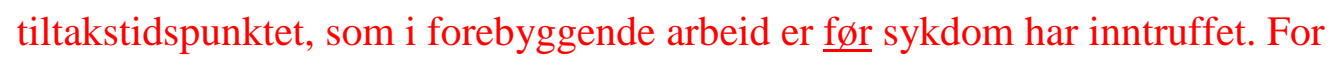
helsetapskriteriet, derimot, velges målpersonens tilstand etter inntreffing av den sykdommen som skal forebygges. Det gjør det veldig lett for utvalget å konkludere at helsetapskriteriet bedre fanger verdien av forebyggende arbeid. Men alvorlighet vil i evaluering av gevinster ved forebyggende tiltak selvsagt referere til den tilstanden en sykdom vil bringe personer i hvis sykdommen ikke forhindres (for eksempel ved HPV-vaksine mot livmorhalskreft). Dette er 'erecting a straw man' fra utvalgets side og helt urimelig sammenlikning. Like urimelig er nest siste setning i første spalte side 124. Når har 'alvorlighet vært et nødvendig vilkår for offentlig finansiering’? Det gir jo ikke en gang mening, i og med at alvorlighet er betegnelsen på et fenomen med grader. Hele avsnittet er så tendensiøst at det er over grensen for uredelighet. 
Et annet eksempel på tendensiøs framstilling er diskusjonen av kriteriet alder i seksjon 8.1.1.

De første avsnittene viser at det i dag gjelder en klar norm om aldersnøytralitet. Utvalget bruker små og perifere avvik fra denne normen til å summere opp med å si at det i dag ' er uenighet om hvilken rolle alder skal spille’ (side 102, annen spalte, annet avsnitt).

Ytterligere et eksempel forekommer der utvalget redegjør for hva folk flest mener om hva ulike typer helsetap bør bety for prioritering. Utvalget nevner 17 studier, hvorav fem sies å støtte vektlegging av helsetap over livet. Vi får vite at 'ikke alle studiene’ gir støtte til forslaget om å legge vekt på helsetapet over livsløpet. Fem av sytten blir altså til ‘ikke alle’. I tillegg kommer at tre av disse fem mangler relevans, jfr pkt 6.3.1 og 6.3.7 ovenfor, og at i hvert fall to mangler kvalitet. Den ene er en norsk studie som utvalgets leder og ene sekretær selv har gjennomført, og som er påvist å ha en alvorlig tvetydighet, jfr pkt 6.11 (12). En annen er en engelsk studie (Dolan og Tsuchuyia 2012) som NICE forkastet pga metodeproblemer. Sistnevnte er påpekt bl.a. i en artikkel i boka'Inequalities in Health’ redigert av Eyal, Hurst, Norheim \& Wikler (13-14).

Et siste eksempel er at referanse 15 brukes, men ikke motleggingen i referanse 16.

\section{Konklusjon}

Jeg viser til kapittel 2: Sammendrag og anbefaling. 


\section{Referanser}

1. Norheim OF, Asada Y. The ideal of equal health revisited. International Journal for Equity in Health 2009,8,40.

2. Ottersen T. Life QALY prioritarianism in priority setting. Journal of Medical Ethics 2013, 39, 175-180.

3. Olsen JA. Priority preferences: 'End of life' does not matter, but total life does. Value in Health 2013, 16, 1063-1066.

4. Nord E, Pinto JL, Richardson J, Menzel P, Ubel P. Incorporating concerns for fairness in numerical evaluations of health programs. Health Economics 1999, 8, 25-39.

5. Stolk E et al Reconciliation of economic concerns and health policy. Illustration using proportional shortfall. Pharmacoeconomics 2004,22,1097-1107.

6. Nord E, Johansen R. Concerns for priority setting in health care. A review of trade-off data in preferences studies and Implications for societal willingness to pay for a QALY. Health Policy 2014,16,281-288.

7. Van de Wetering et al. Balancing efficiency and equity in the Dutch basic benefits package. European Journal of Health Economics 2013,14,107-115.

8. Norheim OF et al. Guidance on priority setting om health care (GPS health): The inclusion of equity criteria not captured by cost-effectiveness analysis. Cost Effectiveness and Resource Allocation 2014,12,18.

9. Hvalbye R, Kobbervik Eivind. Masteroppgaver vår og høst 2012. UiO: Farmasøytisk institutt.

10. Richardson J et al. Maximising health versus sharing. Centre for Health Economics, Monash University, Melbourne.

11. Lindemark F, Norheim O, Johansson K. Making use of equity sensitive QALYs: a case study on identifying the worse off across diseases. Cost Effectiveness and Resource Allocation 2014, 12,16 .

12. Ottersen T, Mæstad O, Norheim OF. Life QALY prioitarianism in priority setting: Empirical quantification of the inherent trade-off. Cost-effectiveness and Resource Allocation 2014, 12.

13. Eyal N, Hurst S, Norheim OF, Wikler D. Inequalities in Health. Concepts, measures and ethics. Oxford University Press 2013.

14. Nord E. Priority to the worse off. Severity of current and future illness versus shortfall in lifetime health. I: Referanse 13, s66-74.

15. Olsen JA. Hva menes med sykdommens alvorlighetsgrad? Tidsskr Nor Legeforening 2013,133,64-67.

16. Nord E. Ikke uklart om alvorlighetsgrad. Tidsskr Nor Legeforening 2013, 133, 499500 . 


\section{VEDLEGG}

\section{Gradering av betalingsvillighet for en QALY: Sammenlikning av alvorlighets- og helsetapskriteriet.}

Det følgende gjelder løpende behandling, for eksempel med legemidler, jfr pkt 6.15 ovenfor.

Man kan fastsette grenseverdier for kostnader per QALY etter dagens alvorlighetskriterium. Man bruker da framtidig helsetap i prosent av forventede gjenværende QALY for vedkommende aldersgruppe (5-7). Hvis man for eksempel legger til grunn en grense på kr 1.000.000 per QALY når alvorligheten er 90 prosent, og man bruker midlere data fra en lang rekke studier av folks vektlegging av alvorlighetsgrad ved valg mellom konkurrerende tiltak, får man anslagsvis følgende tabell (6):

Tabell 1. Betalingsvillighet for en QALY, gradert etter tilstandens alvorlighet.

$\begin{array}{lccccccccc}\text { Alvorlighet (over tid) i prosent: } & 10 & 20 & 30 & 40 & 50 & 60 & 70 & 80 & 90 \\ \text { Ca. grense kr/QALY (1000 kr): } & 200 & 300 & 400 & 500 & 600 & 700 & 800 & 900 & 1.000\end{array}$

I referanse 7 er en tilsvarende gradering stilt opp som en politikkmulighet for Nederland.

På side 128 i utredningen er det en figur som angir utvalgets forslag til grenser for akseptering av kostnader ved å vinne en QALY ('et godt leveår'). Grensene er angitt for ulike helsetapsklasser. For sammenliknbarhet med gradering etter alvorlighetsgrad kan utvalgets forslag framstilles i en litt mer fingradert tabell, der man brukes prosentvis helsetap regnet av et normalt liv på 80 QALY i stedet for absolutt helsetap i antall QALY. F.eks. blir et helsetap over livet på 20 QALY da oversatt til 25 prosent. Figur 9.1 i utredningen blir da litt avrundet til følgende tabell:

Tabell 2. Prioriteringsutvalgets forslag til betalingsvillighet for en QALY, gradert etter helsetap over livet.

$\begin{array}{lllllllll}\text { Helsetap over livet i prosent: } & 0,1 & 1 & 10 & 20 & 30 & 40 & 50 & 60 \\ \text { Grense kr/QALY i 1000 kroner: } & 249 & 250 & 380 & 520 & 650 & 780 & 920 & 1050\end{array}$

Tabell 1 og 2 er like enkle å stille opp. Forskjellene er to:

- I den første er gradienten i betalingsvillighet estimert på grunnlag av omfattende data om befolkningspreferanser. Til sammenlikning er gradienten i utvalgets forslag basert på en 1-2-3 regel som utvalgsmedlemmene selv har funnet rimelig som et utgangspunkt (side 98-99). 
- Den første tabellen er basert på helsevesenets nåværende verdigrunnlag. Den andre er basert på et litt annet verdigrunnlag, der alder vektlegges sterkt.

Utvalgets grenser er basert på en antakelse om at QALY-gevinster på marginen typisk går til personer med et helsetap ned mot 1 QALY over livsløpet. Som nevnt under punkt 6.6 ovenfor, virker et livstidshelsetap på 15-20 QALY for berørte personer på marginen mer plausibelt som gjennomsnitt. Legger en et tap på 20 QALY til grunn, dvs 25 prosent, blir utvalgets gradient omtrent som i tabell 3, dvs betydelig lavere enn i tabell 2.

Tabell 3. Betalingsvillighet for en QALY gradert etter helsetap over livet, gitt alternativ forutsetning om alternativkostnad.

$\begin{array}{llllllllr}\text { Helsetap over livet i prosent: } & 0,1 & 1 & 10 & 20 & 30 & 40 & 50 & 60 \\ \text { Grense kr/QALY i } 1000 \text { kroner: } & 100 & 107 & 170 & 240 & 310 & 380 & 450 & 520\end{array}$

Jeg mener personlig at utvalgets kriterium for gradering er uheldig fordi det medfører urimelig aldersdiskriminering Hvis det først skulle brukes, er utvalgets forslag til grenser uansett for høye gitt dets egen logikk, fordi det synes å være gjort en urimelig antakelse om helsetap over livet hos berørte pasienter på marginen. Dette sies med forbehold om at min lesing av utredningen er riktig på dette punkt, da utvalget som nevnt i pkt 6.6 ovenfor ikke har svart på spørsmål om det.

Hvis man tenker seg tabell 1 ovenfor anvendt på tiltak for personer som er ved starten av livet, blir prosentene for alvorlighet sammenfallende med prosentvis helsetap over hele livet fram til 80 år. Dvs at den evidensbaserte graderingen som tabell 1 viser, kan være til hjelp til bestemming av hvordan gradering bør være hvis en i stedet skulle ønske å bruke helsetap over livet som graderingskriterium. Denne betraktningen gir mer støtte til anslagene i tabell 3 enn til anslagene i tabell 2.

Til slutt: Alle tall i tabeller som ovenfor er svært avhengige av hvilket absolutt nivå man legger seg på for QALY assosiert med en bestemt grad av alvorlighet eller helsetap. Utvalget har valgt å forankre sine tall i anslag fra England om hvor mye QALY som tapes på marginen ved reduksjon av eksisterende aktiviteter når NICE påtvinger helsevesenet nye kostnader knyttet til det å tilby en ny teknologi ('displacement cost'). Det engelske anslaget er i seg selv diskutabelt metodemessig. Det 'oversettes’ av utvalget til et tall for Norge basert på en analyse fra Helsedirektoratet. Oversettelsen bør i seg selv valideres. Å forankre i 'alternativkostnad' er teoretisk fornuftig, men det er vanskelig å verifisere slike anslag. I tillegg gjør det seg gjeldende praktisk-økonomiske hensyn i offentlig budsjettering som kan trumfe teoretisk riktige løsninger. Til syvende og sist må derfor myndigheter kanskje litt uavhengig av teori bestemme hvor langt man synes man har råd til å strekke seg i å akseptere kostnader ved en QALY, dvs bestemme betalingsvillighet for QALY for personer som er svært dårlig stilt. Så kan gradering av betalingsvillighet for QALY for personer som er mindre dårlig stilt, som eksemplifisert i tabellene ovenfor, bestemmes gjennom bruk av evidens om vanlige menneskers preferanser og gjennom nærmere diskusjon. 